\title{
Aspekty wprowadzania średniego poziomu zawartości etanolu do benzyny silnikowej. Część 2. Nieaddytywny wpływ etanolu na lotność
}

\begin{abstract}
W artykule przedstawiono wyniki badań zależności składu frakcyjnego i prężności par benzyny od zawartości etanolu powyżej $10 \%(V / V)$. Przedmiotem badań były mieszaniny zawierające $10 \div 25 \%(V / V)$ etanolu oraz jedna mieszanina z 22\% $(V / V)$ ETBE.
\end{abstract}

Słowa kluczowe: benzyna silnikowa E10+, etanol, prężność par, destylacja.

\section{Aspects of blending a mid level content of ethanol to motor gasoline. Part 2. Non-linear impact of ethanol on volatility}

The article presents the results of studies of the dependence of distillation and vapor pressure of gasoline on ethanol content more than $10 \%(V / V)$. The subject of the study were mixtures containing $10 \div 25 \%(V / V)$ ethanol and one mixture containing $22 \%(V / V)$ ETBE.

Key words: petrol E10+, ethanol, vapor pressure, distillation.

\section{Wstęp}

Bioetanol może stwarzać określone problemy zarówno w produkcji benzyn silnikowych o wymaganej jakości, jak i trudności w czasie dystrybucji, magazynowania i użytkowania. Badania nad rozwiązaniem tych problemów są prowadzone w wielu krajach stosujących benzyny ze zwiększo- nym udziałem bioetanolu. Jednak specyfika i warunki techniczno-technologiczne poszczególnych producentów takiego paliwa wymagają podjęcia badań, które pomogą w sposób efektywny wykorzystać zalety bioetanolu oraz zniwelować jego wady jako komponentu benzyny silnikowej.

\section{Koncepcja badań}

Celem badań było określenie wpływu zwiększonej zawartości bioetanolu na nieaddytywne właściwości bezołowiowej benzyny silnikowej.

W początkowym etapie pracy zaplanowano zbadanie podstawowych właściwości fizykochemicznych i użytkowych bazowej bezołowiowej benzyny silnikowej 95 oraz właściwości zastosowanego w badaniach bioetanolu.
W kolejnym etapie pracy zaplanowano zbadanie wpływu różnych udziałów bioetanolu na normowane nieaddytywne lotnościowe parametry jakościowe bezołowiowej benzyny silnikowej 95 o różnym udziale lekkich frakcji $\mathrm{C}_{4}$, takie jak prężność par i skład frakcyjny.

Uzyskane wyniki badań tych parametrów planowano porównać z parametrami uzyskanymi dla próbek benzyny E10. 


\section{Metodyka badań}

Do oceny jakości benzyny bezołowiowej wykorzystywano metody badań przedstawione w normie PN-EN 228:2013-04, a do oceny jakości etanolu - w normie PN-EN 15376:2012.
Badania prężności par wykonywano metodą ASTM D 4953 , a składu frakcyjnego metodą PN-EN ISO 3405.

Wynik prężności par podano jako DVPE.

\section{Przedmiot badań}

Przedmiotem badań były próbki paliw E10+, tj. zawierające powyżej $10 \%(V / V)$ etanolu - 15\%, 20\%, 25\% (V/V). Dodatkowo na potrzeby porównań skomponowano dwie próbki benzyny E10, z których jedna zawierała 10\% ( $/ / V)$ etanolu, a druga $22 \%(V / V)$ eteru etylowo-tert-butylowego (ETBE).

Próbki o objętości 1 litra zestawiono w szklanych butelkach litrowych, odmierzając obliczone ilości składników odpowiednim cylindrem miarowym. Przygotowanie próbek odbywało się w temperaturze pokojowej, a temperatura składników pozostawała bez zmian. Po skomponowaniu próbki poddano ujednorodnianiu techniką wytrząsania ręcznego, a następnie umieszczono je $\mathrm{w}$ chłodziarce $\mathrm{w}$ temperaturze poniżej $0^{\circ} \mathrm{C}$ w celu ustabilizowania zawartości.

Do skomponowania powyższych próbek wykorzystano bazową benzynę bezołowiową $95 \mathrm{w}$ gatunku przejściowym (E0/P) i zimowym (E0/Z). Oznaczone jej właściwości podano w tablicy 1 . Właściwości benzyny silnikowej 95, zarówno wersji przejściowej, jak i zimowej, spełniały wymagania normy PN-EN 228:2013-04.

$\mathrm{Z}$ kolei wyniki badania bioetanolu paliwowego podano w tablicy 2. Właściwości etanolu spełniały wymagania normy PN-EN 15376:2012.

Tablica 1. Właściwości bazowej bezołowiowej benzyny 95

\begin{tabular}{|c|c|c|c|}
\hline Parametr & $\mathrm{E} 0 / \mathrm{P}$ & $\mathrm{E} 0 / \mathrm{Z}$ & $\begin{array}{l}\text { Wymagania jakościowe według } \\
\text { PN-EN 228:2013-04 }\end{array}$ \\
\hline 1. Liczba oktanowa (LOB) & 95,3 & 96,1 & $\min .95,0$ \\
\hline 2. Liczba oktanowa (LOM) & 85,4 & 85,5 & $\min .85,0$ \\
\hline 3. Gęstość w temp. $15^{\circ} \mathrm{C}\left[\mathrm{kg} / \mathrm{m}^{3}\right]$ & 738,8 & 739,6 & $720 \div 775$ \\
\hline \multicolumn{4}{|l|}{ 4. Skład frakcyjny: } \\
\hline - do $70^{\circ} \mathrm{C}$ odparowuje (E70) $[\%(V / V)]$ & $\begin{array}{c}35,8 \\
-\end{array}$ & 38,6 & $\begin{array}{l}\text { okres przejściowy: } 20,0 \div 50,0 \\
\text { okres zimowy: } 22,0 \div 50,0\end{array}$ \\
\hline - do $100^{\circ} \mathrm{C}$ odparowuje (E100) $[\%(V / V)]$ & 55,0 & 56,7 & $46,0 \div 71,0$ \\
\hline - do $150^{\circ} \mathrm{C}$ odparowuje (E150) [\% (V/V)] & 89,7 & 88,1 & $\min .75,0$ \\
\hline - koniec destylacji $\left[{ }^{\circ} \mathrm{C}\right]$ & 193,2 & 192,6 & maks. 210 \\
\hline - pozostałość [\% $(V / V)]$ & 1,0 & 1,1 & maks. 2 \\
\hline 5. Prężność par [kPa] & $\begin{array}{c}60,8 \\
- \\
\end{array}$ & $8 \overline{4}, 3$ & $\begin{array}{l}\text { okres przejściowy: } 45,0 \div 90,0 \\
\text { okres zimowy: } 60,0 \div 90,0\end{array}$ \\
\hline 6. Indeks lotności & 859 & 1113 & maks. 1150 \\
\hline 7. Zawartość ołowiu [mg/l] & $<2,5$ & $<2,5$ & maks. 5 \\
\hline 8. Zawartość żywic obecnych [mg/100 ml] & 1 & 1 & maks. 5 \\
\hline 9. Okres indukcyjny [minuta] & $>360$ & $>360$ & maks. 360 \\
\hline 10. Zawartość siarki [mg/kg] & 8,4 & 7,5 & maks. 10 \\
\hline 11. Zawartość benzenu [\% $(V / V)]$ & 0,42 & 0,89 & maks. 1,00 \\
\hline $\begin{array}{l}\text { 12. Badanie działania korodującego na płytce z miedzi } \\
\text { [stopień] }\end{array}$ & klasa 1 & klasa 1 & klasa 1 \\
\hline 13. Zawartość zw. tlenowych [\% $(V / V)]$ & nie zawiera & nie zawiera & jak w normie ${ }^{*}$ \\
\hline 14. Zawartość tlenu $[\%(\mathrm{~m} / \mathrm{m})]$ & nie zawiera & nie zawiera & maks. 2,7 \\
\hline \multicolumn{4}{|l|}{ 15. Skład grupowy według FIA [\% $(V / V)]$ : } \\
\hline - parafino-nafteny & 59,3 & 56,7 & - \\
\hline - olefiny & 10,2 & 13,4 & maks. 18,0 \\
\hline - aromaty & 30,5 & 29,9 & maks. 35,0 \\
\hline
\end{tabular}


Tablica 2. Wyniki analizy bioetanolu (EtOH)

\begin{tabular}{|l|c|c|}
\hline \multicolumn{1}{|c|}{ Parametr } & Bioetanol & $\begin{array}{c}\text { Wymagania jakościowe } \\
\text { dla bioetanolu według } \\
\text { PN-EN } 15376: 2012\end{array}$ \\
\hline 1. Zawartość etanolu i wyższych nasyconych alkoholi $[\%(\mathrm{~m} / \mathrm{m})]$ & 99,8 & min. 98,7 \\
\hline 2. Zawartość wyższych nasyconych $\left(\mathrm{C}_{3}-\mathrm{C}_{5}\right)$ monoalkoholi $[\%(\mathrm{~m} / \mathrm{m})]$ & $<0,001$ & maks. 2,0 \\
\hline 3. Zawartość metanolu [\% $(\mathrm{m} / \mathrm{m})]$ & $<0,001$ & maks. 1,0 \\
\hline 4. Zawartość wody [\% $(\mathrm{m} / \mathrm{m})]$ & 0,137 & maks. 0,300 \\
\hline 5. Całkowita kwasowość $(\mathrm{wyrażona} \mathrm{jako} \mathrm{zawartość} \mathrm{kwasu} \mathrm{octowego)}[\%(\mathrm{~m} / \mathrm{m})]$ & 0,004 & maks. 0,007 \\
\hline 6. Przewodność elektryczna $[\mu \mathrm{S} / \mathrm{cm}]$ & $<2,0$ & maks. 2,5 \\
\hline 7. Zawartość chlorków nieorganicznych $[\mathrm{mg} / \mathrm{kg}]$ & $<4,0$ & maks. 6,0 \\
\hline 8. Zawartość siarczanu $[\mathrm{mg} / \mathrm{kg}]$ & 3,2 & maks. 4,0 \\
\hline 9. Zawartość miedzi $[\mathrm{mg} / \mathrm{kg}]$ & $<0,07$ & maks. 0,100 \\
\hline 10. Zawartość fosforu $[\mathrm{mg} / \mathrm{l}]$ & $<0,15$ & maks. 0,15 \\
\hline 11. Zawartość suchej pozostałości po odparowaniu $[\mathrm{mg} / 100 \mathrm{ml}]$ & $<10$ & maks. 10 \\
\hline 12. Zawartość siarki $[\mathrm{mg} / \mathrm{kg}]$ & $<5,0$ & maks. 10,0 \\
\hline
\end{tabular}

\section{Ocena zmian parametrów lotności benzyny z różnym udziałem bioetanolu}

Liczne badania [np. 1-4, 5, 7] nad zastosowaniem bioetanolu do komponowania benzyny silnikowej wskazują, że oddziałuje on w określony sposób na jej parametry jakościowe. Przy czym wpływ na niektóre parametry jest nieaddytywny. Dotyczy to, między innymi, składu frakcyjnego i prężności par. Do predykcji wielkości/wartości tych parametrów wykorzystywane mogą być np. modele kreowane przez sieci neuronowe. Analizę danych i tworzenie struktur, które potrafią samodzielnie przetwarzać dane analityczne, autorzy publikacji [8] oparli na przykładzie systemów zdolnych do interpretowania zależności pomiędzy składem chromatograficznym benzyny silnikowej a wielkościami opisującymi jej nieaddytywne parametry jakościowe, na przykład prężność par i parametry składu frakcyjnego, tj. E70 i E100.

W niniejszych badaniach oznaczono te parametry doświadczalnie w próbkach benzyn z zawartością bioetanolu od 15\% (V/V) (E15) do 25\% (V/V) (E25) i porównawczo w próbkach z zawartością 10\% $(V / V)$ etanolu (E10) i z zawartością 22\% (V/V) ETBE (E10/22ETBE) oraz w próbkach niezawierających etanolu (E0).

\section{Skład frakcyjny}

Jak wspomniano w pierwszej publikacji [6], skład frakcyjny jest jednym z najistotniejszych parametrów benzyny silnikowej, mającym zasadnicze znaczenie przy ocenie jej właściwości eksploatacyjnych. Przebieg krzywej składu frakcyjnego zależy od składu chemicznego benzyny silnikowej. Ilość frakcji odparowującej do $70^{\circ} \mathrm{C}$ (E70) charakteryzuje właściwy rozruch silnika zimnego, natomiast ilość frak- cji odparowującej do $100^{\circ} \mathrm{C}(\mathrm{E} 100)$ - szybkość nagrzewania się silnika oraz właściwą jego pracę podczas eksploatacji.

Na rysunkach 1 i 2 zaprezentowano wyniki uzyskane dla badanych próbek benzyn o zawartości od 10\% do 25\% (V/V) bioetanolu w benzynie silnikowej z okresu przejściowego E0/P i okresu zimowego E0/Z. Na rysunkach przedstawiono także krzywą destylacji benzyny silnikowej E10/ETBE22, zawierającej 22\% (V/V) ETBE.

Zaobserwowano zdecydowany wpływ zawartości bioetanolu na krzywą destylacji obu benzyn silnikowych w zakresie temperatur od $60^{\circ} \mathrm{C}$ do $130^{\circ} \mathrm{C}$. Zwiększanie udziału bioetanolu powodowało $\mathrm{w}$ tym zakresie temperatur wzrost ilości frakcji odparowujących w danej temperaturze w porównaniu do benzyny E0, tj. węglowodorowej. W przypadku udziału 25\% (V/V) zaobserwowane zmiany były takie same jak w przypadku udziału 20\% ( V/V). Duży udział ETBE w próbce E10/ETBE22 wygenerował widoczne zmiany w przebiegu krzywej destylacji benzyny węglowodorowej E0 w kierunku wzrostu ilości frakcji odparowujących w zakresie $80 \div 130^{\circ} \mathrm{C}$.

Analizując wpływ zawartości etanolu powyżej 10\% $(\mathrm{V} / \mathrm{V})$, a także 22\% (V/V) ETBE na ilość paliwa odparowującego do $70^{\circ} \mathrm{C}$ i do $100^{\circ} \mathrm{C}$ obliczono wartości zmian parametrów E70 i E100 badanych próbek benzyny z różnymi zawartościami bioetanolu, a także dane o zmianie parametrów E70 i E100 benzyny E0/P i E0/Z po dodaniu do niej 22\% ( V/V) ETBE. Dane te przedstawiono w formie graficznej na rysunku 3.

Analiza zaprezentowanych wyników wskazuje, że wzrost zawartości bioetanolu powyżej 10\% $(V / V)$ w benzynie bezołowiowej E10+, zarówno z okresu przejściowego, jak i okresu zimowego, generował wzrost parametru E100 od kilkunastu 


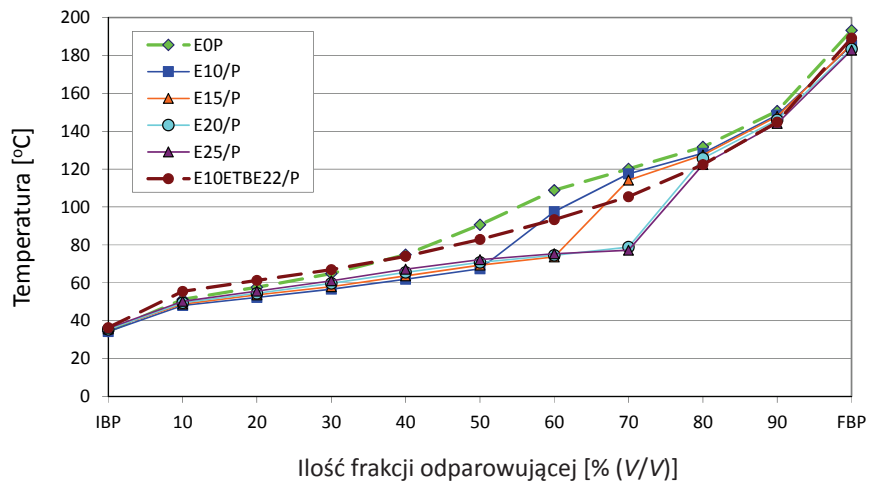

Rys. 1. Wpływ zawartości 15\% do 25\% (V/V) bioetanolu na przebieg krzywej destylacji benzyny silnikowej z okresu przejściowego (E0/P)

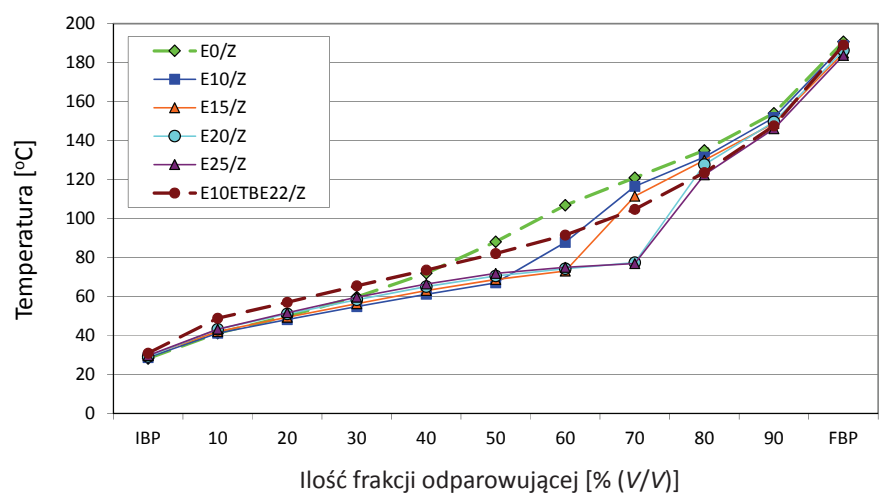

Rys. 2. Wpływ zawartości 15\% do 25\% (V/V) bioetanolu na przebieg krzywej destylacji benzyny silnikowej $\mathrm{z}$ okresu zimowego (E0/Z)

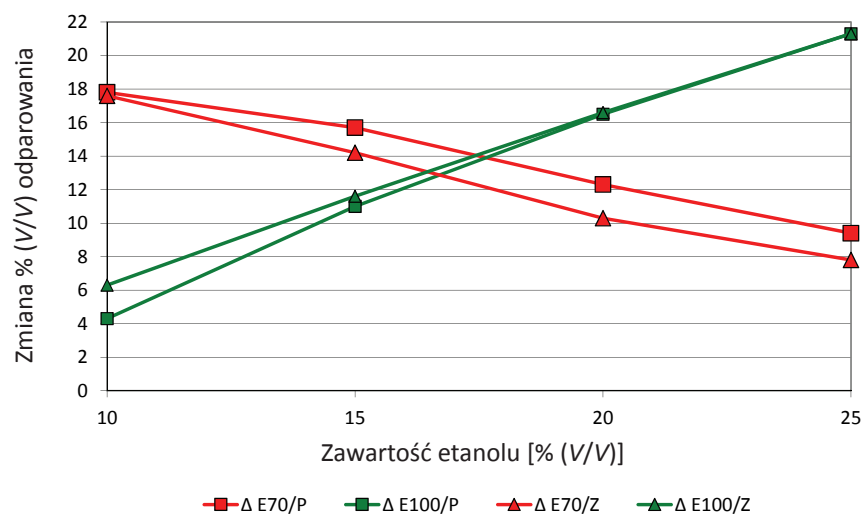

Rys. 3. Zmiany $\Delta$ E70 i $\Delta$ E100 benzyn E0/P i E0/Z w zależności od udziału bioetanolu

do kilkudziesięciu procent. Z kolei parametr E70 ulegał obniżeniu od kilkunastu do kilku procent. Różnice pomiędzy wartościami zmian tych parametrów uzyskane dla obu rodzajów benzyn (tj. z okresu przejściowego i zimowego) pozostawały niewielkie.

W związku z zaobserwowanymi na rysunku 3 tendencjami otrzymane wartości parametrów E70 i E100 dla benzyn z obu okresów klimatycznych w zależności od udziału bioetanolu przedstawiono także na rysunku 4. Na wykresie kolorowymi prostokątami zaznaczono limity dla okresu przejściowego i zimowego wg normy PN-EN 228:2013-04 dla benzyny zawierającej maksymalnie 3,7\% $(\mathrm{m} / \mathrm{m})$ tlenu, tj. benzyny E10. Benzyna E10, zarówno z okresu przejściowego, jak i zimowego, przekraczała limit ustalony dla parametru E70, jednak dodawanie większych ilości etanolu powodowało, że parametr E70 przy zawartości etanolu powyżej 15\% (V/V) mieścił się w limitowanym zakresie. Odwrotna sytuacja występowała w przypadku parametru E100. Zarówno próbka E10, jak i próbki do zawartości 20\% (V/V) etanolu mieściły się w limitowanym zakresie. Natomiast 25-proc. $(V / V)$ udział etanolu przekraczał górny limit dla parametru E100.

Próbki benzyny E0/P i E0/Z pochodziły z okresu przejściowego i zimowego, dlatego też zawierały względnie wysoki udział lekkich frakcji $\mathrm{C}_{4}$. Powodowało to uzyskiwanie wyższych ilości frakcji odparowujących do określonych temperatur, niż prawdopodobnie miałoby to miejsce w przypadku braku frakcji $\mathrm{C}_{4} \mathrm{w}$ benzynie. Wynika stąd wniosek, że dla 25-proc. $(V / V)$ zawartości bioetanolu w benzynie z okresu przejściowego i zimowego trzeba będzie skorygować zawartość frakcji $\mathrm{C}_{4} \mathrm{w}$ benzynie, jeśli limity parametru E100 ustalone dla benzyny E10 pozostaną niezmienione w nowej specyfikacji paliwa E10+, w przypadku, gdy górna granica zawartości etanolu wynosić będzie 25\% (V/V).

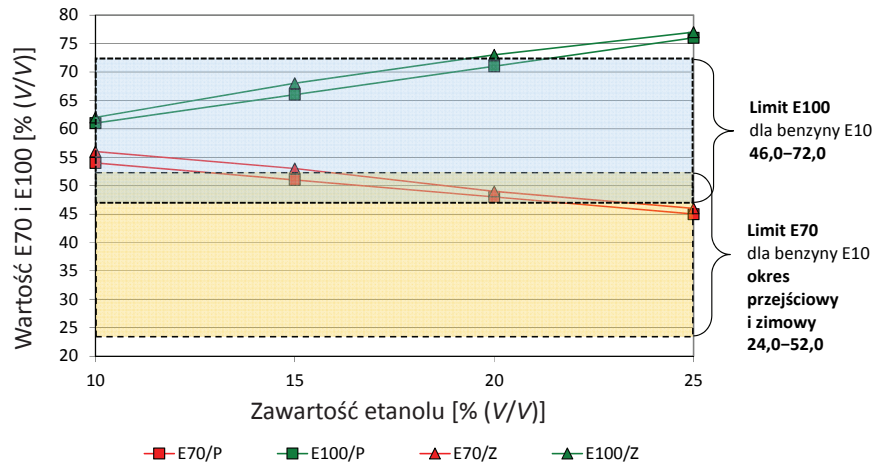

Rys. 4. Wartości parametrów E70 i E100 w zależności od udziału bioetanolu w benzynie E0/P i E0/Z

\section{Prężność par}

Prężność par jest drugim istotnym parametrem lotności benzyny silnikowej, który ma znaczenie zarówno dla właściwej eksploatacji silnika samochodowego, jak i dla odpo- wiedniej jakości powietrza atmosferycznego, o czym wspomniano w pierwszej publikacji [8]. Sezonowe sterowanie wartością prężności par benzyny bezołowiowej jest niezbędne 
ze względu na warunki klimatyczne danego kraju. Bioetanol, chociaż sam posiada niską prężność par (około $19 \mathrm{kPa}$ ), w połączeniu z węglowodorami, w zależności od ich charakteru chemicznego, uzyskuje wysoką blendingową prężność par, podnosząc tym samym prężność par benzyny bazowej. Uzyskane wyniki badań prężności par przedmiotowych próbek benzyn stanowily podstawę do obliczenia zmian wartości prężności par benzyny bazowej w zależności od udziału w niej etanolu. Na rysunku 5 przedstawiono uzyskane wyniki w formie graficznej.

Największy jej przyrost otrzymano dla benzyny E10 zawierającej $10 \%(V / V)$ bioetanolu. Przyrost ten był większy dla próbki o niższej prężności par benzyny bazowej (E0/P). Dalszy wzrost zawartości etanolu w benzynie powyżej 10\% $(V / V)$ generował coraz niższe przyrosty prężności par. W tym miejscu należy zaznaczyć, że parametr prężności par, niezależnie od rodzaju benzyny, pozostawał w zakresach limitów ustalonych dla okresu przejściowego i zimowego w normie PN-EN 228:2013-04. Wynika stąd, że dodatek bioetanolu do benzyny E10+ nie stwarzał zagrożenia niespełnienia limitów ani w okresie przejściowym, ani w zimowym.

Dodatkową informacją jest wynik badania prężności par benzyny E10/ETBE22, zawierającej zamiast bioetanolu eter ETBE w ilości 22\% $(V / V)$. Porównanie zmiany prężności par

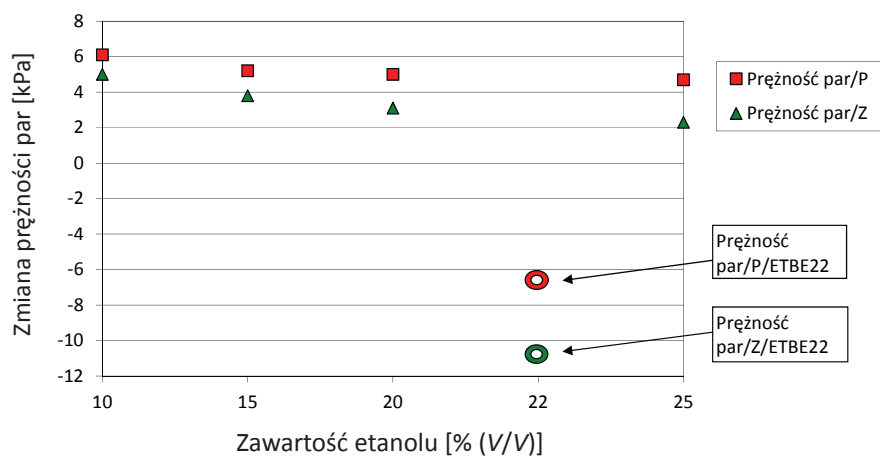

Rys. 5. Zmiana wartości prężności par w zależności od zawartości bioetanolu w benzynie E0/P i E0/Z

benzyny E10 ( $+6,1$ w okresie przejściowym i $+5,0$ w okresie zimowym) i benzyny E10/ETBE22 ( $-6,5$ w okresie przejściowym i $-11,0 \mathrm{w}$ okresie zimowym) daje dodatkową wiedzę o diametralnie różnym wpływie dwóch podstawowych biokomponentów na parametr prężności par. ETBE obniżył prężność par benzyny E0/P (o mniejszej zawartości frakcji $\mathrm{C}_{4}$ ) praktycznie o tę samą wartość, o którą prężność tę podwyższył dodatek $10 \%(V / V)$ bioetanolu. W przypadku benzyny E0/Z (o większej zawartości frakcji $\mathrm{C}_{4}$ ) ETBE ponad dwukrotnie obniżył wartość jej prężności par w porównaniu z wartością wzrostu prężności par tej benzyny po dodaniu $10 \%(V / V)$ bioetanolu.

\section{Podsumowanie}

Przeprowadzone prace pozwoliły zaobserwować zdecydowany wpływ zawartości bioetanolu powyżej 10\% $(V / V)$ na krzywą destylacji benzyny silnikowej w temperaturach od $60^{\circ} \mathrm{C}$ do $130^{\circ} \mathrm{C}$. W tym zakresie następował wzrost ilości frakcji odparowującej w porównaniu $\mathrm{z}$ benzyną węglowodorową. Zwiększenie zawartości etanolu powyżej 10\% $(V / V)$ powodowało łagodne zmniejszanie się przyrostów dla E70 i drastyczny wzrost przyrostów dla E100, odwrotnie niż w przypadku benzyny silnikowej zawierającej etanol w zakresie $1 \div 10 \%(V / V)$. Zaobserwowano również, że duży udział
ETBE w próbce benzyny E10 wygenerował widoczne zmiany w przebiegu krzywej destylacji w zakresie temperatur $80 \div 130^{\circ} \mathrm{C}$ w porównaniu z krzywą destylacji benzyny węglowodorowej, a także w porównaniu z krzywą destylacji benzyny E10 zawierającej tylko etanol w ilości 10\% $(V / V)$.

$\mathrm{W}$ badaniach przeprowadzonych $\mathrm{w}$ niniejszej pracy potwierdzono, że dodatek bioetanolu do bazowej węglowodorowej benzyny bezołowiowej podnosi jej prężność par. Efekt odwrotny, tj. obniżenie prężności par, spowodował dodatek ETBE w ilości 22\% $(V / V)$.

\section{Wnioski}

Na podstawie przeprowadzonych badań można wysnuć następujące wnioski:

- wpływ etanolu na krzywą składu frakcyjnego przy jego udziale w formule benzyny silnikowej powyżej $10 \%(V / V)$ jest różny od wpływu tego biokomponentu przy jego udziale do $10 \%(V / V)$,

- niezwykle istotny jest wynikający z badań fakt, że o ile w benzynie E10 etanol wywierał duży wpływ na prężność par i E70, czyli parametry związane z rozruchem zimnego i ciepłego silnika, to w przypadku benzyny E10+ ten wpływ skupia się w większym stopniu na parametrze E100, czyli parametrze stabilnej pracy silnika,

- eter etylowo-tert-butylowy dozowany do benzyny silnikowej E10 w maksymalnej dopuszczalnej ilości 22\% (V/V) będzie powodował znaczne obniżenie prężności par benzyny finalnej w zależności od prężności par benzyny bazowej, co z technologicznego punktu widzenia może stwarzać dodatkowe możliwości produkcyjne,

- zastosowanie w przyszłości zwiększonej powyżej $10 \%(V / V)$ ilości etanolu w benzynie silnikowej wyma- 
ga dalszych badań, szczególnie dla krajowych warunków jej produkcji, między innymi w zakresie właściwo- ści eksploatacyjnych i użytkowych, a także wpływu na infrastrukturę magazynowo-dystrybucyjną.

Prosimy cytować jako: Nafta-Gaz 2016, nr 9, s. 755-760, DOI: 10.18668/NG.2016.09.11

Artykuł nadesłano do Redakcji 21.03.2016 r. Zatwierdzono do druku 23.05.2016 r.

Artykuł powstał na podstawie pracy statutowej pt. Badanie zmian nieaddytywnych parametrów jakościowych benzyny silnikowej E15-E25 o zwiększonej zawartości bioetanolu - praca INiG - PIB na zlecenie MNiSW; nr zlecenia: 0014/TP/15/01, nr archiwalny: DK-4101-14/15.

\section{Literatura}

[1] Andersen V. F., Anderson J. E., Wallington T. J., Mueller S. A., Nielsen O. J.: Distillation Curves for Alcohol-Gasoline Blends. Energy Fuels 2010, vol. 24, no. 4, s. 2683-2691. DOI: 10.1021/ ef9014795.

[2] Bruno T. J., Wolk A., Naydich A.: Composition-Explicit Distillation Curves for Mixtures of Gasoline with Four-Carbon Alcohols (Butanols). Energy Fuels 2009, vol. 23, no. 4, s. 2295-2306. DOI: 10.1021/ef801117c.

[3] Danek B., Rogowska D.: Destylacja benzyny silnikowej z zawartościa do $10 \%(\mathrm{~V} / \mathrm{V})$ etanolu-obliczanie jej parametrów metoda addytywnych wskaźników mieszania. Nafta-Gaz 2014, nr 3, s. 192-196.

[4] de Menezes E. W., Cataluña R., Samios D., da Silva R.: Addition of an azeotropic ETBE/ethanol mixture in eurosupertype

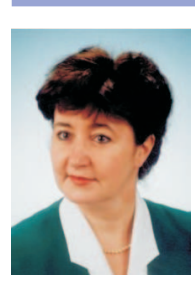

Dr inż. Martynika PAŁUCHOWSKA

Główny specjalista badawczo-techniczny

w Zakładzie Paliw i Procesów Katalitycznych.

Instytut Nafty i Gazu - Państwowy Instytut Badawczy

ul. Lubicz 25 A

31-503 Kraków

E-mail: martynika.paluchowska@inig.pl gasolines. Fuel 2006, vol. 85, no. 17-18, s. 2567-2577. DOI: 10.1016/j.fuel.2006.04.014.

[5] Muzikova Z., Pospisil M., Sebor G.: Volatility and phase stability of petrol blends with ethanol. Fuel 2009, vol. 88, no. 8, s. 1351-1356. DOI: 10.1016/j.fuel.2009.02.003.

[6] Pałuchowska M., Haduch B.: Aspekty wprowadzania średniego poziomu zawartości etanolu do benzyny silnikowej. Część 1 . Nafta-Gaz 2016, nr 2, s. 3-41. DOI: 10.18668/NG2016.02.06.

[7] Pałuchowska M., Rogowska D.: Wplyw bioetanolu na nieaddytywne właściwości benzyny silnikowej. Nafta-Gaz 2009, nr 1, s. 21-28.

[8] Tadeusiewicz R., Haduch B.: Wykorzystanie sieci neuronowych do analizy danych i pozyskiwania wiedzy w systemie ekspertowym do oceny parametrów benzyn silnikowych. Nafta-Gaz 2015, nr 10, s. 776-785.

Mgr inż. Bogusław HADUCH

Starszy specjalista badawczo-techniczny, kierownik Biura Kontroli. Instytut Nafty i Gazu - Państwowy Instytut Badawczy

ul. Lubicz 25 A

31-503 Kraków

E-mail: boguslaw.haduch@inig.pl 